\title{
Expression in vivo of additional plasmid-mediated proteins during intestinal infection with Yersinia enterocolitica serotype 08
}

\author{
M. NAUMANN, C. HANSKI* and E. O. RIECKEN \\ Freie Universität Berlin, Klinikum Steglitz, Abteilung für Innere Medizin mit Schwerpunkt Gastroenterologie, \\ Hindenburgdamm 30, 1000 Berlin 45, Germany
}

\begin{abstract}
Summary. The decisive aspect of Yersinia enterocolitica virulence in vivo is the ability of the plasmid-bearing bacteria to resist the immune response within the host tissue. The expression of plasmid-mediated virulence proteins was investigated in the intestinal lumen and in the Peyer's patches of infected mice. Three novel plasmid-mediated outer-membrane proteins have been identified with antisera raised against bacteria grown in vivo. When the bacteria were grown in the intestinal lumen, all plasmid-coded proteins known to be expressed in vitro, except the $26-\mathrm{Kda}$ protein were expressed. Additionally, a novel outer-membrane protein of $23 \mathrm{Kda}$ was synthesised. After penetration into the Peyer's patches, two further proteins of 240 and $210 \mathrm{Kda}$ were expressed. None of these three proteins was detected in the outer membrane of bacteria grown in vitro. By contrast, plasmid-coded released proteins, which are abundantly synthesised in $\mathrm{Ca}^{2+}$-deficient media in vitro, were not detectable in the ileal lumen nor in the tissue of infected Peyer's patches, which suggests that they are not required for $Y$. enterocolitica pathogenesis.
\end{abstract}

\section{Introduction}

Enteropathogenic Yersinia enterocolitica strains, as well as virulent strains of $Y$. pestis and $Y$. pseudotuberculosis, harbour a 42-46-Mda plasmid ${ }^{1}$ coding for several outer-membrane proteins (YOPs), which are considered to be potential virulence factors. ${ }^{2}$ The plasmid also codes for growth inhibition in $\mathrm{Ca}^{2+}$. deficient medium ${ }^{3}$ and concomitant release of several proteins-released proteins (RPs) and V antigen ${ }^{4,5}$ into the medium. Some of these proteins are structurally and immunologically related to YOPs. ${ }^{6,7}$ Experiments with Yersinia spp. carrying recombinant plasmid DNA indicate the relevance of some YOPs for pathogenesis. The absence of the proteins YOP20, YOP25 or YOP48 of $Y$. enterocolitica serotype O9 reduced markedly the virulence of this species in mice. ${ }^{8,9}$ Similarly, the elimination of YOP $2 b$ or YOP5 from the outer membrane of $Y$. pseudotuberculosis ${ }^{10,11}$ or YOPE, YOPK and YOPL from $Y$. pestis ${ }^{12}$ by transposon mutagenesis decreased the virulence of these species in mice.

Most published work on plasmid-coded yersinia outer-membrane proteins has been done with organisms grown in vitro in synthetic media. However, environmental factors such as various nutrients, temperature, oxygen and carbon dioxide content can influence the macromolecular composition of $Y$. enterocolitica $^{13}$ and possibly also the YOPs. Recent

Received 12 Oct. 1990; accepted 4 Jan. 1991

*Correspondence should be sent to Dr C. Hanski. evidence obtained by immunohistochemistry, and transmission and scanning electronmicroscopy indicates that the decisive aspect of $Y$. enterocolitica virulence in vivo is the ability of these bacteria to survive within the intestinal tissue, ${ }^{14-16}$ i.e., the proteins expressed in vivo may be crucial for virulence.

There is little information on the composition of the outer membrane of Yersinia spp. in the environment found in the host during infection. Skurnik and Poikonen ${ }^{17}$ examined by immunohistochemistry the expression of plasmid-coded outer-membrane proteins of $Y$. enterocolitica serotype $\mathrm{O} 3$ in the rat intestinal lumen and tissue. However, neither the expression of single YOPs nor of RPs in vivo has been studied in detail. The aim of the present work was to investigate whether proteins are released in vivo during $Y$. enterocolitica infection. Furthermore, the expression of plasmid-coded proteins in the lumen of the intestine or in the Peyer's patches was compared with that in bacteria grown in vitro.

\section{Materials and methods}

\section{Bacterial strains and in-vitro growth conditions}

A plasmid-bearing $Y$. enterocolitica strain (NCTC 10938, denoted $\mathrm{O}^{+}$) and an isogenic plasmid-free strain (NCTC 10598, denoted $\mathrm{O8}^{-}$) of serotype O8, were obtained from the National Collection of Type Cultures, Colindale Avenue, London. For optimal 
expression of RPs and YOPs in vitro, Y. enterocolitica was grown, in Brain-Heart Infusion Broth (BHB) (Oxoid) overnight at $24^{\circ} \mathrm{C}$. This culture was then diluted 1 in 15 with fresh BHB, incubated with shaking at $37^{\circ} \mathrm{C}$ for $2 \mathrm{~h}$, supplemented with edetic acid and incubated for a further $2 \mathrm{~h}$.

\section{Growth and recovery of $Y$. enterocolitica from the intestinal lumen}

The CD-1 mice (each weighing c. $30 \mathrm{~g}$ ) were starved for $18 \mathrm{~h}$ before they were anaesthetised with $150 \mu \mathrm{l}$ of Ketanest $(50 \mathrm{mg} / \mathrm{ml}$ ) (Parke, Davis and Co., Munich, Germany). The technique of Wolf et al. ${ }^{18}$ was used for ligation of the ileum. The small intestine was made accessible by midventral laparotomy and a 10-cm loop was prepared in the ileum with string ligature. Ligation was performed without interrupting the blood supply or motility within the ligated part of the small intestine.

Bacteria were grown overnight in $\mathrm{BHB}$ at $24^{\circ} \mathrm{C}$, pelleted by centrifugation and resuspended in BHB. The suspension $(250 \mu \mathrm{l})$ containing $c .10^{8}$ organisms, was injected into the ligated ileal segments. The animals were killed after $4 \mathrm{~h}$, and the fluid from the loops was obtained by extrusion and subsequent lavage with $5 \mathrm{ml}$ of sterile saline. The fluid was first centrifuged at $800 \mathrm{~g}$ for $5 \mathrm{~min}$ to remove epithelial cells. Bacteria were then pelleted from the supernate by centrifugation at $6000 \mathrm{~g}$ for $20 \mathrm{~min}$.

\section{Oral infection of mice}

Infection of mice was performed as described previously. ${ }^{15}$ For each of four experiments, five male CD-1 mice (age 8 weeks; weight $30 \mathrm{~g}$ ) were deprived of water for $18 \mathrm{~h}$ and then each mouse was given $5 \mathrm{ml}$ of a suspension containing c. $5 \times 10^{8}$ bacteria $/ \mathrm{ml}$ to drink.

\section{Recovery of bacteria from infected Peyer's patches}

The mice were killed by cervical dislocation 72$84 \mathrm{~h}$ after infection. Peyer's patches from the small intestine were excised, washed twice in sterile saline and homogenised as described previously. ${ }^{19}$ The number of bacteria was determined in dilutions of the homogenate by counting the colonies formed on Endo agar. The homogenates of Peyer's patches obtained from five mice contained $c .10^{8} \mathrm{cfu}$. The bacteria were recovered from homogenates by differential centrifugation. After centrifugation at $800 \mathrm{~g}$ for $5 \mathrm{~min}$ at $4^{\circ} \mathrm{C}$, intact murine cells and large cell fragments were pelleted. The supernate was centrifuged at $6000 \mathrm{~g}$ for $20 \mathrm{~min}$ and yielded predominantly bacterial sediment.

\section{Preparations of outer membranes and soluble protein fractions}

Supernates from the $6000 \mathrm{~g}$ centrifugation were sterilised by membrane filtration and then centrifuged at $100000 \mathrm{~g}$ for $1 \mathrm{~h}$ at $4^{\circ} \mathrm{C}$. The soluble protein fraction was precipitated with trichloroacetic acid (TCA, final concentration $10 \%$ ).

To obtain outer membranes, the bacterial suspension was exposed to five cycles, each of $15 \mathrm{~s}$, of ultrasonication in $15 \mathrm{ml}$ of buffer containing $10 \mathrm{mM}$ Tris- $\mathrm{HCl}, \mathrm{pH} 7 \cdot 8,1 \mathrm{~mm}$ mercaptoethanol and $5 \mathrm{~mm}$ edetic acid, at full power with a Vibra cell (Sonics and Materials Inc., Danbury, USA) as described by Bölin et $a .^{20}$ After centrifugation at $6000 \mathrm{~g}$ for $30 \mathrm{~min}$ at $4^{\circ} \mathrm{C}$, membranes remaining in the supernate were sedimented by ultracentrifugation at $100000 \mathrm{~g}$ for $1 \mathrm{~h}$ at $4^{\circ} \mathrm{C}$. The inner bacterial membranes in the pellet were solubilised for $30 \mathrm{~min}$ at $4^{\circ} \mathrm{C}$ with sodium $\mathrm{N}$ lauroylsarcosinate $0.5 \%$ and $1 \mathrm{mM}$ mercaptoethanol. After centrifugation at $100000 \mathrm{~g}$ for $1 \mathrm{~h}$ at $4^{\circ} \mathrm{C}$, the sedimented outer membranes were resuspended in distilled water and centrifuged again. Outer membranes and TCA-precipitated soluble proteins were dissolved in sample buffer ${ }^{21}$ and boiled for $5 \mathrm{~min}$.

\section{Preparation of antisera}

Rabbit anti-RP antisera and monospecific antisera against single RPs were induced as described previously. ${ }^{7}$ For pre-adsorption of the orally induced (p.o.) rabbit antisera against $\mathrm{O}^{+}$or $\mathrm{O}^{-}$strains, the antisera were diluted 1 in 50 in phosphate-buffered saline (PBS) and incubated with formalin-fixed, washed bacteria of the $\mathrm{O}^{-}$strain as reported previously. ${ }^{19}$ The pre-adsorbed rabbit p.o. antisera reacted with all the plasmid-coded yersinia proteins known to be expressed in vitro. ${ }^{19}$

\section{Iodination of $\operatorname{Ig} G$}

Rabbit immunoglobulin $G$ against the whole RP fraction of strain $\mathrm{O8}^{+}$was affinity-purified on Protein A-Sepharose and radio-iodinated by the lactoperoxidase method as described previously. ${ }^{7}$

\section{Autoradiography}

For detection of virulence-associated antigens, the solubilised membranes were separated by sodium dodecyl sulphate-polyacrylamide gel electrophoresis (SDS-PAGE) on polyacrylamide $11.5 \%$ gels and transferred on to PVDF-Immobilon membrane (Millipore). After blocking with bovine serum albumin (BSA) $4 \%$ and gelatin $0.1 \%$ in PBS for $15 \mathrm{~min}$ at $37^{\circ} \mathrm{C}$, the membrane was washed with washing buffer (BSA $0.1 \%$, gelatin $0.1 \%$ in PBS) and incubated overnight at $4{ }^{\circ} \mathrm{C}$ with $5 \mathrm{ml}$ of the same buffer containing ${ }^{125} \mathrm{I}-$ labelled anti-RP-IgG (c. $\left.9.6 \times 10^{5} \mathrm{dpm}\right)$. The membrane was then washed three times with washing buffer, dried, and autoradiographs were produced by overnight exposure, at $70^{\circ} \mathrm{C}$, to Hyperfilm ${ }^{\circledR}$-MP (Amersham Buchler, Braunschweig, Germany) with an X-Omatic intensifying screen (Eastman Kodak Co., Rochester, NY, USA). 


\section{Immunoblotting}

Immunoblot analysis of virulence-associated proteins separated by SDS-PAGE with $11.5 \%$ gels was performed by the method of Towbin et al. ${ }^{22}$ PVDFmembranes with transblotted antigens were blocked as described for autoradiography. Then the membranes were agitated overnight at $4^{\circ} \mathrm{C}$ with the appropriate dilutions of antisera in BSA $0.1 \%$ and gelatin $0.1 \%$ in PBS. After washing in PBS-BSAgelatin, the antibodies were detected with immunogold-labelled goat anti-rabbit immunoglobulin G (diluted 1 in 400) (Auro Probe One, Janssen, Biotech, Olen, Belgium) followed by signal enhancement with silver salt solution (IntenseBL, Janssen, Biotech), as recommended by the manufacturer.

\section{Results}

\section{Expression of plasmid-mediated proteins in bacteria grown in the intestinal lumen}

The initial interaction between an enteropathogenic bacterium and the host immune system takes place in the intestinal lumen, where the bacteria are suspended in the intestinal fluid or adhere to the mucus layer. The pre-adsorbed, p.o. rabbit antisera reacted specifically with plasmid-coded yersinia proteins known to be expressed in vitro. ${ }^{19}$ Immunoblotting of outer membranes from bacteria grown in vivo with these antisera showed that after growth for $4 \mathrm{~h}$ in this environment, yersiniae exhibit distinct alterations of their surface composition. The detection of the YOPs was performed with a pre-absorbed, p.o. antiserum against strain $\mathrm{O}^{+}$. The $26-\mathrm{Kda}$ YOP expressed in vitro is repressed during growth in the intestinal lumen. By contrast, a 24-Kda YOP was produced in greater amounts and a further novel YOP of $23 \mathrm{Kda}$ was expressed in the lumen (fig. 1). The 24-Kda polypeptide was not a proteolytic product of the $26-\mathrm{Kda}$ peptide; indeed the monospecific rabbit antiserum against the 24-Kda protein did not cross-react with the 26-Kda peptide. ${ }^{7}$ Prominent protein bands of 110 and $116 \mathrm{Kda}$ present in the plasmid-containing strain grown in vivo were also detected in the plasmid-free strain grown under the same conditions i.e. they were chromosomally-coded.

In the yersiniae-free fluid obtained from intestinal loops containing $>10^{8}$ bacteria, no RPs were detected after TCA-precipitation and immunoblotting of precipitates. This result indicates that protein release does not occur at all in the intestinal lumen or is largely repressed, because this number of bacteria would produce large amounts of RPs under favourable conditions in vitro. The absence of detectable amounts of RPs was not due to adsorption to the tissue nor to complete proteolysis; the RPs are resistant to luminal or tissue proteases and their adsorption to tissue components in homogenates was negligible.

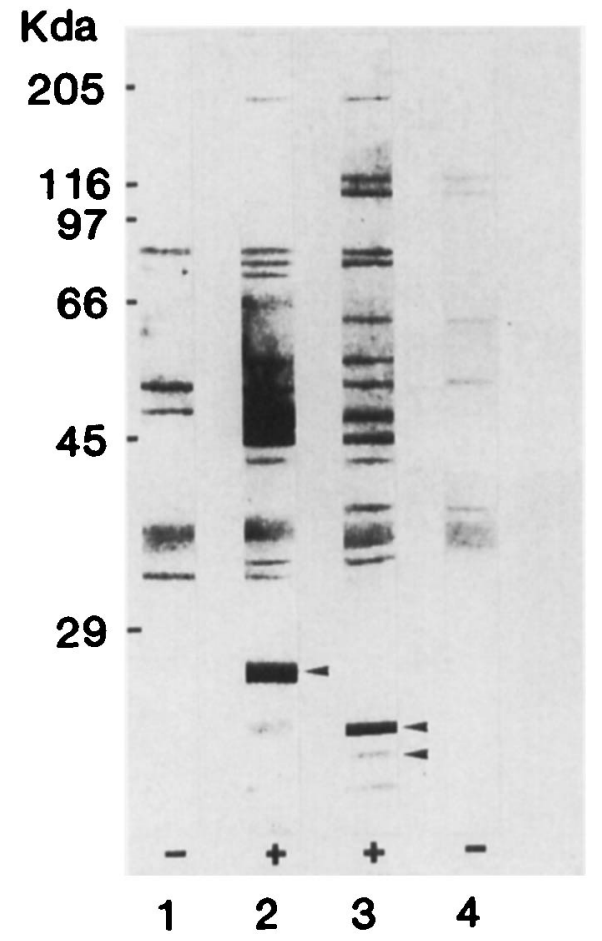

Fig. 1. Immunoblot of the outer-membrane proteins from $Y$. enterocolitica serotype $\mathrm{O} 8$ from cultures grown in BHB $(1,2)$ or in mice intestinal loops $(3,4):-$, outer membranes from plasmid-free bacteria; +, outer membranes from plasmid-bearing bacteria. The arrows indicate differences in expression of the plasmid-coded proteins in vitro $(1,2)$ and in vivo $(3,4)$. The positions of corresponding $\mathrm{M}_{\mathrm{r}}$ markers are shown on the left of the figure.

\section{Expression of plasmid-mediated membrane proteins in Peyer's patches}

The YOPs expressed in vivo are the likely components responsible for resistance of yersiniae to the immune reaction of the host. Therefore, outer membranes from bacteria recovered from Peyer's patches were examined. As shown in fig. 2 (track 2) the main plasmid-coded YOPs present in vitro were also expressed by the bacteria grown in the tissue of Peyer's patches. As described previously, ${ }^{7}$ the monospecific anti-RP antisera against RP24 and RP56 cross-reacted with the corresponding YOPs (fig. 2, tracks 3 and 5). The monospecific antiserum against RP34 detected an additional $36-\mathrm{Kda}$ YOP on the bacterial membrane (fig. 2, track 4). This protein was not detected on the membranes obtained from the bacteria grown in vitro or in the intestinal lumen (fig. 1, tracks 2 and 3), probably because of the large amount of the porin protein in this $M_{r}$ range. ${ }^{23}$ Immunoblotting of the membranes with a pre-adsorbed antiserum against $\mathrm{O}^{+}$bacteria revealed that, besides the YOPs present in the bacteria grown in vitro and the 23-Kda protein expressed in the intestinal lumen, two further novel proteins of 240 and $210 \mathrm{Kda}$ were expressed in bacteria grown within the Peyer's patches (fig. 3, track 3). Because of the inaccessibility of some integral membrane proteins of intact bacteria, the pre-adsorption was never complete. To ensure that the detected 


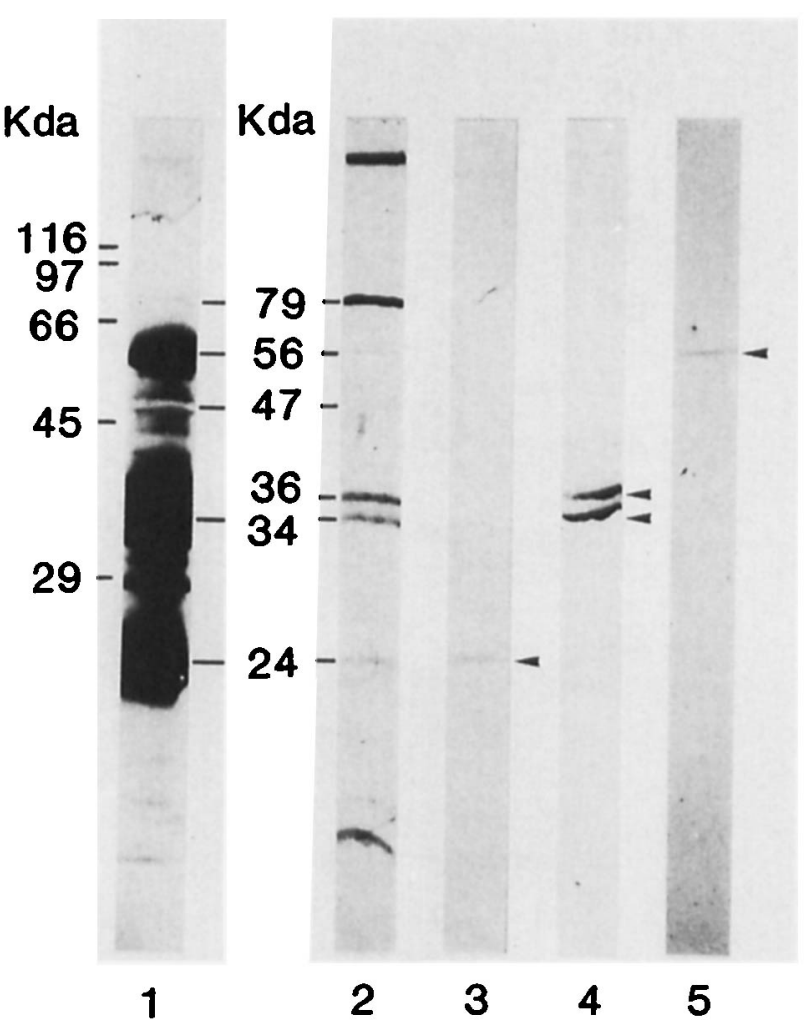

Fig. 2. Immunoblot of outer membranes of $Y$. enterocolitica serotype O8 recovered from infected Peyer's patches with rabbit anti-RP antisera. Tracks: 1, separated RPs from bacteria grown in vitro (the lane was overloaded to make the 79-Kda RP visible); 2 , outer membranes immunoblotted with the rabbit antiserum against all RPs $; 3,4$ and 5 , outer membranes immunoblotted with monospecific antisera induced against single RPs of 24,34 and $56 \mathrm{Kda}$.

proteins were not the result of incomplete preadsorption, the same membranes were immunoblotted with a pre-adsorbed antiserum against $08^{-}$bacteria. As shown in fig. 3 (track 4), none of the plasmid-coded proteins recognised by the $\mathrm{O}^{+}$antiserum, was detected. The $160 \mathrm{Kda}$ protein band in track 3 of fig. 3 was the proteolytic product of the P1 protein.

\section{Investigation of released proteins in vitro and in vivo}

To ensure high sensitivity of detection, ${ }^{125} \mathrm{I}$-labelled anti-RP IgG was used for immunoblotting and autoradiography. The TCA-precipitate of soluble proteins released from $10^{6}$ bacteria grown in vitro and, in parallel samples, the precipitate of the soluble fraction of the Peyer's patches homogenate containing $10^{7}$ bacteria, were investigated. As shown in fig. 4, large amounts of proteins released in vitro were detected (track 1), whereas there was no evidence for protein release in vivo (track 2).

\section{Discussion}

The present work defines the alterations of $Y$. enterocolitica outer-membrane proteins during growth of bacteria in the intestinal lumen or the intestinal tissue. These alterations are of particular interest because the effects on the bacteria of growth under different conditions in vivo may have profound effects on the host-parasite interaction. As reported recently, yersiniae preferentially enter the intestinal tissue via $\mathbf{M}$ cells in the epithelium of Peyer's patches and proliferate beneath the epithelium, from where they spread into the lamina propria. ${ }^{14,15}$

The molecular mechanisms by which $Y$. enterocolitica attaches to, penetrates, and survives within tissue are unknown. The expression of plasmid-coded outermembrane proteins plays an important but as yet incompletely defined, role in yersinia infection. ${ }^{10,11,24,25}$ These antigens could be expressed at different stages of infection and thus contribute to bacterial survival in different environments. Indeed, the data presented here indicate an additional expression of three, hitherto undetected, plasmid-mediated proteins, suggesting that the conditions in vivo modulate bacterial gene expression. Within $4 \mathrm{~h}$ of intraluminal growth, $Y$. enterocolitica expressed a novel 23$\mathrm{Kda}$ protein on its outer membrane. Moreover, the expression of the 24-Kda YOP was strongly enhanced and the expression of the 26-Kda YOP was suppressed. After passage into the Peyer's patches tissue, two additional YOPs of 240 and $210 \mathrm{Kda}$ were expressed. Immunoblot analysis of yersiniae grown in the peritoneal cavity confirmed this result; in the membranes of the bacteria grown in the peritoneal cavity, the same YOPs as those identified in the membrane from bacteria grown in the Peyer's patches were present. ${ }^{26}$ The $24-\mathrm{Kda}$ protein, which is conserved in all three pathogenic Yersinia spp., ${ }^{27}$ inhibits the primary host defence. ${ }^{28}$ Another protein of $36 \mathrm{Kda}$ was detected in membranes of bacteria grown in vivo in the tissue of Peyer's patches but not in the intestinal lumen nor in vitro. However, it appears that this protein is also present in cells grown in vitro, but its detection is prevented by the large amount of the porin protein present in the same $\mathrm{M}_{\mathrm{r}}$ range. ${ }^{23}$ During growth of bacteria in Peyer's patches, expression of the porin and the "heat-modifiable" protein OmpA is suppressed, thus allowing the detection of the $36 \mathrm{Kda}-$ YOP. The loss of the porin and OmpA proteins in $Y$. enterocolitica serotype 09 under certain conditions in vitro was previously described by Cornelis et al. ${ }^{29}$ They showed also that transposon-mutagenised bacteria deficient in YOP40.8 and YOP37.4 express the porin protein and $\mathrm{OmpA}$, which indicates that one or both YOPs have a modifying influence on expression of these proteins. All these alterations are detectable with orally induced pre-adsorbed rabbit antiserum against the $\mathrm{O}^{+}$strain. None of the three YOPs expressed in vivo reacted with the pre-adsorbed $\mathrm{O}^{-}$ antiserum, thus excluding the possibility that they are chromosomally coded, or that they are of host rather than bacterial origin.

In cell lysates of $Y$. enterocolitica serotype $\mathrm{O} 3$ grown in peritoneal capsules, Skurnik ${ }^{30}$ detected several 


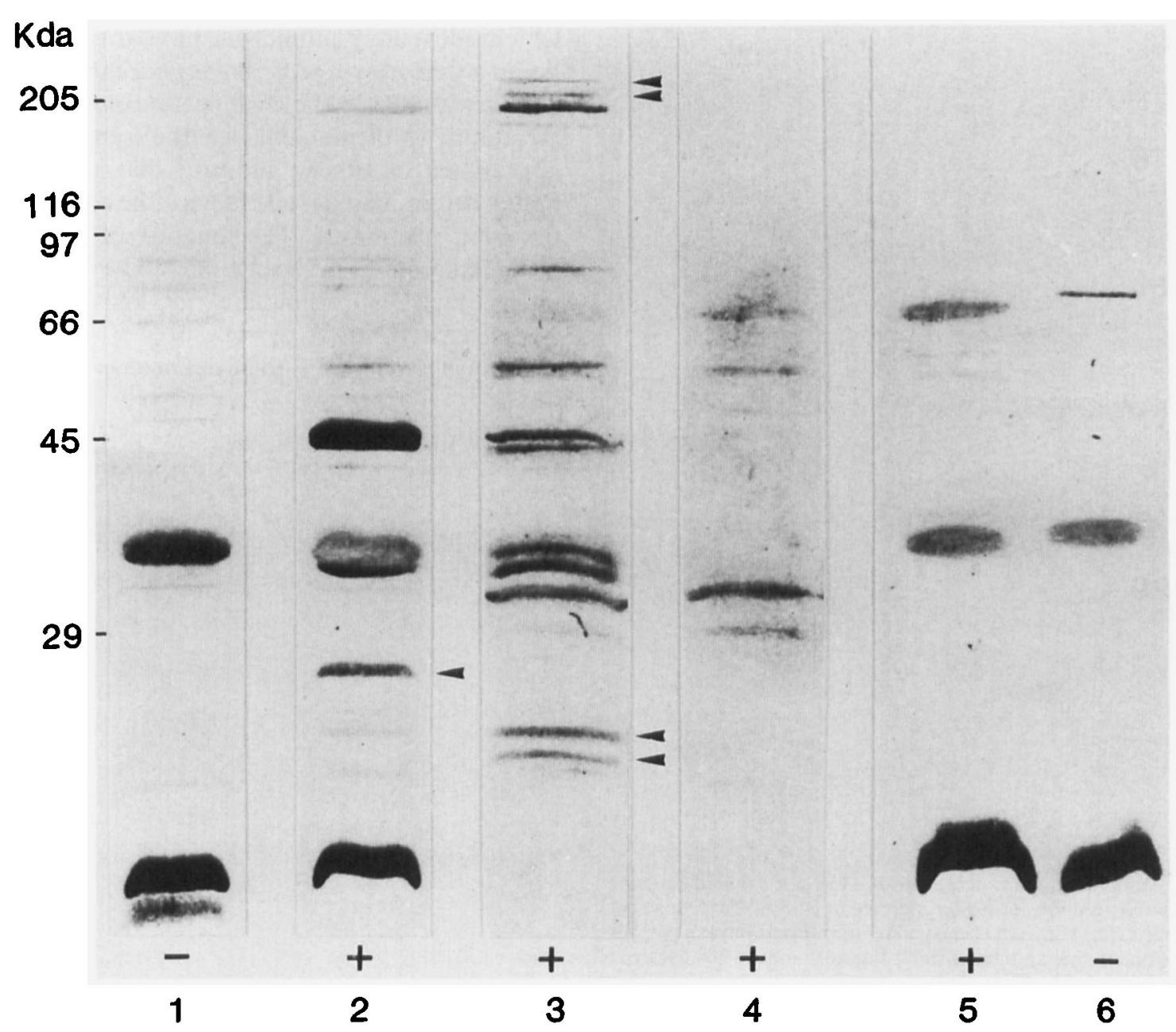

Fig. 3. Immunoblot of outer membranes of $Y$. enterocolitica serotype $O 8$ from bacteria grown in vitro $(1,2,5,6)$ or recovered from infected Peyer's patches $(3,4)$. The electrophoresed and blotted proteins were detected with different antisera: tracks 1-3, p.o. antiserum against $08^{+}$ strain, pre-adsorbed with $\mathrm{O}^{-}$bacteria; 4-6 p.o. antiserum against $\mathrm{O}^{-}$strain, pre-adsorbed with $\mathrm{O}^{-}$bacteria; -, outer membranes from plasmid-free bacteria; +, outer membranes from plasmid-bearing bacteria. The arrows indicate the differences in expression of plasmidcoded proteins expressed in vitro and in vivo. The positions of corresponding $\mathbf{M}_{\mathrm{r}}$ markers are shown on the left of the figure.

additional proteins. This was the first indication that gene expression in yersiniae is modulated by the growth conditions in vivo. Furthermore, in the intestinal lumen and intestinal tissue the expression of protein $\mathrm{P} 1$ was shown by immunohistochemistry with a monoclonal antibody. ${ }^{17}$ The present work extends these data by showing the expression of the hitherto known and, additionally, novel outer-membrane proteins in the intestine (summarised in the table). Recently Carniel et al. ${ }^{31}$ found several new chromosomally-coded outer-membrane proteins in $Y$. enterocolitica serotype 08 strain 8081 grown in iron-deficient media. The proteins expressed in the intestine and described in the present work are plasmid-mediated, i.e., are different from the proteins detected by Carniel et al. ${ }^{31}$.

RPs or V antigen could be detected neither in the intestinal lumen nor in the tissue of the infected Peyer's patches. It is concluded that the release of these antigens is suppressed in vivo probably because of the high $\mathrm{Ca}^{2+}$ concentration. ${ }^{19}$ Price and Straley ${ }^{32}$ described recently an avirulent mutant of $Y$. pestis that showed growth restriction and V-antigen secretion also in the presence of calcium. This indicates the importance of proliferation during pathogenesis. Since growth restriction and protein release appear to be strictly correlated, protein release in the $\mathrm{Ca}^{2+}$-rich extracellular fluid may impair the survival of the bacteria.

It is possible that the RPs and V antigen could be released within macrophages, where the $\mathrm{Ca}^{2+}$-concentration is very low. ${ }^{33}$ However, the number of phagocytosed bacteria is small (Hanski et al., unpublished results) and the RPs, if released, were not detectable. This result corresponds to the data of Rosquist et al. ${ }^{28}$ who found no expression of plasmidcoded proteins by $Y$. pestis grown intracellularly in HeLa cells.

The antigens identified as unique to bacteria grown in vivo might be useful markers for growth conditions 


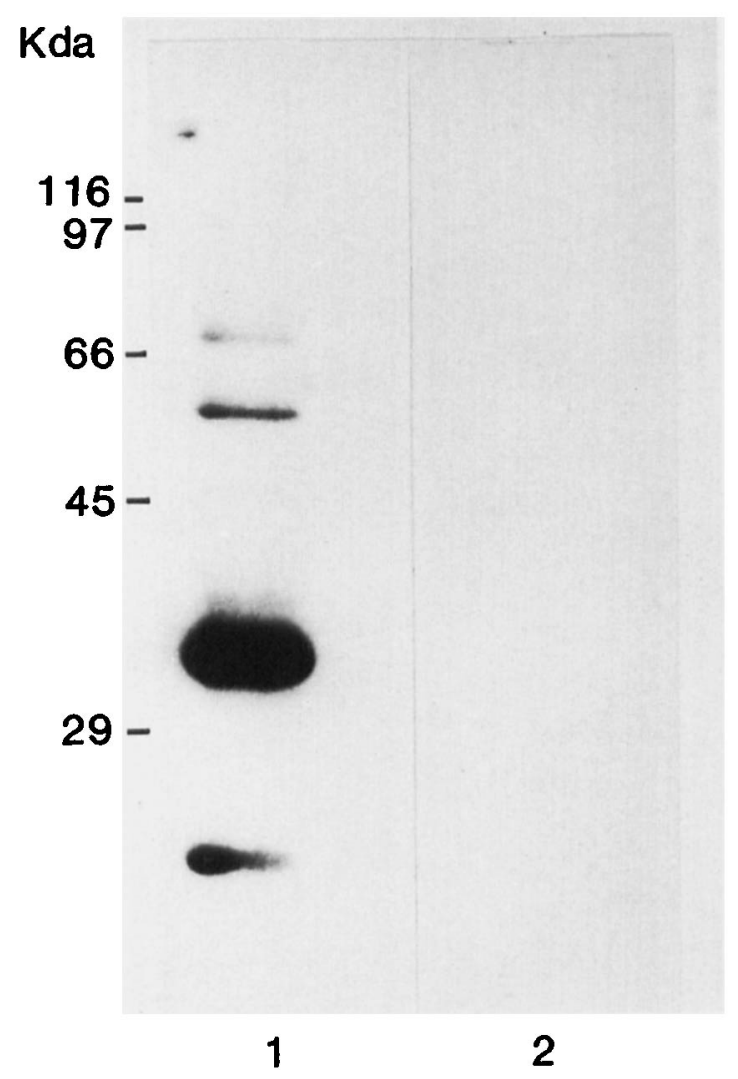

Fig. 4. Autoradiographic detection of TCA-precipitated proteins from soluble fractions of bacteria grown in vitro in $\mathrm{Ca}^{2+}$-deficient medium (track 1) or from homogenates of infected Peyer's patches (2). The precipitate applied to track 1 corresponds to $10^{6}$ bacteria and that in track 2 to $10^{7}$ bacteria. which adequately mimic the in-vivo situation. Our findings that growth of $Y$. enterocolitica in the intestine of mice resulted in the disappearance of some outermembrane proteins and, at the same time, the appearance of others, indicate that the intestinal milieu determines, at least in part, the composition of the outer membrane. The function of the plasmidmediated proteins induced in vivo and the factors that induce their expression are not known. Also the significance of these novel antigens for bacterial survival in vivo remains to be defined.

This work was supported by grant $\mathrm{Ha} 152 / 1-2$ from the Deutsche Forschungsgemeinschaft and by the Maria-Sonnenfeld-Gedächtnisstiftung.

Table. Relative molecular masses of the YOPs of $Y$. enterocolitica serotype $\mathrm{O} 8$ grown in vitro or in vivo determined by SDS-PAGE

\begin{tabular}{l|rrr} 
& \multicolumn{2}{|c}{$\mathbf{M}_{\mathrm{r}}(\mathrm{Kda})$ of proteins from bacteria grown } \\
\cline { 2 - 4 } Protein & & \multicolumn{2}{c}{ in vivo } \\
\cline { 2 - 4 } & in vitro & luminal & Peyer's patches \\
\hline YOP240 & & $\mathrm{ND}$ & 240 \\
YOP210 & $\mathrm{ND}$ & $\mathrm{ND}$ & 210 \\
P1 & $\mathrm{ND}$ & 180 & 180 \\
YOP79 & 180 & 79 & 79 \\
YOP56 & 79 & 56 & 56 \\
YOP47 & 56 & 47 & 47 \\
YOP45* & 47 & 45 & 45 \\
YOP42 & 45 & 42 & 36 \\
YOP36 & 42 & $\mathrm{ND}$ & 34 \\
YOP34 & ND & 34 & ND \\
YOP26 & 34 & $\mathrm{ND}$ & 24 \\
YOP24 & 26 & 24 & 23 \\
YOP23 & 24 & 23 & \\
\hline
\end{tabular}

ND, not detected.

*Subunit of protein P1

\section{References}

1. Portnoy DA, Wolf-Watz H, Bölin I, Beeder AB, Falkow S. Characterization of common virulence plasmids in Yersinia species and their role in the expression of outer membrane proteins. Infect Immun 1984; 43: 108-114.

2. Ben-Gurion R, Shafferman A. Essential virulence determinants of different Yersinia species are carried on a common plasmid. Plasmid $1981 ; 5: 183-187$.

3. Gemski P, Lazere JR, Casey T. Plasmid associated with pathogenicity and calcium dependency of Yersinia enterocolitica. Infect Immun 1980; 27: 682-685.

4. Heesemann J, Algermissen B, Laufs R. Genetically manipulated virulence of Yersinia enterocolitica. Infect Immun 1984; 46: $105-110$. 
5. Portnoy DA, Blank HF, Kingsbury DT, Falkow S. Genetic analysis of essential plasmid determinants of pathogenicity in Yersinia pestis. J Infect Dis 1983; 148: 297-304.

6. Forsberg $\AA$, Bölin $\mathrm{H}$, Norlander L, Wolf-Watz H. Molecular cloning and expression of calcium-regulated, plasmidcoded proteins of $Y$. pseudotuberculosis. Microb Pathog 1987; 2: 123-137.

7. Naumann M, Hanski C, Friedrich B, Riecken EO. A rapid in situ expression test for virulence-associated proteins of Yersinia enterocolitica. J Microbiol Methods 1990; 11 : 8393.

8. Mulder B, Michiels T, Simonet M, Sory M-P, Cornelis G. Identification of additional virulence determinants on the pYV plasmid of Yersinia enterocolitica. Infect Immun 1989; 57: 2534-2541.

9. Sory MP, Cornelis G. Yersinia enterocolitica $0: 9$ as a potential live oral carrier for protective antigens. Microb Pathog $1988 ; 4: 431-442$.

10. Bölin I, Wolf-Watz H. The plasmid-encoded Yop $2 b$ protein of Yersinia pseudotuberculosis is a virulence determinant regulated by calcium and temperature at the level of transcription. Mol Microbiol 1988; 2: 237-245.

11. Forsberg $\AA$, Wolf-Watz $\mathrm{H}$. The virulence protein Yop 5 of Yersinia pseudotuberculosis is regulated at transcriptional level by plasmid-pIB1-encoded trans-acting elements controlled by temperature and calcium. Mol Microbiol 1988 2: 121-133.

12. Straley SC, Cibull ML. Differential clearance and host-pathogen interactions of $\mathrm{YopE}^{-}$and $\mathrm{YopK}^{-} \mathrm{YopL}^{-}$Yersinia pestis in BALB/c mice. Infect Immun 1989; 57: 1200-1210.

13. Grönberg A, Kihlström E. Structural variations and growth potential of Yersinia enterocolitica under different culture conditions. APMIS 1989; 97: 227-235.

14. Grützkau A, Hanski C, Hahn H, Riecken EO. Involvement of M-cells in the bacterial invasion of Peyer patches: a common mechanism shared by Yersinia enterocolitica and other enteroinvasive bacteria. Gut 1990; 31 : 1011-1015.

15. Hanski C, Kutschka U, Schmoranzer HP et al. Immunohistochemical and electron microscopic study of interaction of Yersinia entercolitica serotype 08 with intestinal mucosa during experimental enteritis. Infect Immun 1989; 57: 673678.

16. Lian C-J, Hwang WS, Kelly JK, Pai CH. Invasiveness of Yersinia enterocolitica lacking the virulence plasmid: an invivo study. J Med Microbiol 1987; 24: 219-226.

17. Skurnik M, Poikonen K. Experimental intestinal infection of rats by Yersinia enterocolitica O:3. A follow-up study with specific antibodies to the virulence plasmid specified antigens. Scand J Infect Dis 1986; 18: 355-364.

18. Wolf JL, Rubin DH, Finberg $R$ et al. Intestinal $M$ cells: a pathway for entry of reovirus into the host. Science 1981; 212: $471-472$
19. Hanski C, Naumann M, Hahn M, Riecken EO. Determinants of invasion and survival of Yersinia enterocolitica in intestinal tissue: an in vivo study. Med Microbiol Immunol $1989 ; 178: 289-296$.

20. Bölin I, Norlander L, Wolf-Watz H. Temperature-inducible outer membrane protein of Yersinia pseudotuberculosis and Yersinia enterocolitica is associated with the virulence plasmid. Infect Immun 1982; 37: 506-512.

21. Laemmli UK. Cleavage of structural proteins during the assembly of the head of bacteriophage T4. Nature 1970; 227: 680-685.

22. Towbin H, Staehelin T, Gordon J. Electrophoretic transfer of proteins from polyacrylamide gels to nitrocellulose sheets: procedure and some applications. Proc Natl Acad Sci USA $1979 ; 76: 4350-4354$.

23. Ogasawara M, Kobayashi S, Arai S et al. A heat-modifiable outer membrane protein carries an antigen specific for the species Yersinia enterocolitica and Yersinia pseudotuberculosis. J Immunol 1985; 135: 1430-1436.

24. Lian C-J, Hwang WS, Pai CH. Plasmid-mediated resistance to phagocytosis in Yersinia enterocolitica. Infect Immun 1987; 55: $1176-1183$.

25. Rosquist R, Bölin I, Wolf-Watz H. Inhibition of phagocytosis in Yersinia pseudotuberculosis: a virulence plasmid-encoded ability involving the Yop2b protein. Infect Immun 1988; 56: 2139-2143

26. Hanski C, Naumann M, Grützhau A et al. Humoral and cellular defence against intestinal murine infection with Yersinia enterocolitica. Infect Immun 1991; 59: 1106-1111.

27. Bölin I, Forsberg A, Norlander L, Skurnik M, Wolf-Watz H. Identification and mapping of the temperature-inducible, plasmid-encoded proteins of Yersinia. Infect Immun 1988; 56: $343-348$.

28. Rosqvist R, Forsberg $\AA$, Rimpiläinen M, Bergman T, WolfWatz $H$. The cytotoxic protein YopE of Yersinia obstructs the primary host defence. Mol Microbiol 1990; 4: 657-667.

29. Cornelis G, Sory MP, Laroche Y, Derclaye I. Genetic analysis of the plasmid region controlling virulence in Yersinia enterocolitica $0: 9$ by Mini-Mu insertions and lac gene fusions. Microb Pathog 1986; 1 : 349-359.

30. Skurnik M. Expression of antigens encoded by the virulence plasmid of Yersinia enterocolitica under different growth conditions. Infect Immun 1985; 47: 183-190.

31. Carniel E, Mazigh D, Mollaret HH. Expression of ironregulated proteins in Yersinia species and their relation to virulence. Infect Immun 1987; 55: 277-280.

32. Price SB, Straley SC. 1crH, a gene necessary for virulence of Yersinia pestis and for the normal response of $Y$. pestis to ATP and calcium. Infect Immun 1989; 57: 1491-1498.

33. Pollack C, Straley SC, Klempner MS. Probing the phagolysosomal environment of human macrophages with a $\mathrm{Ca}^{2+}$ responsive operon fusion in Yersinia pestis. Nature 1986; 322: 834-836. 